\title{
AN INTERVENTION PROGRAMME FOR WOMEN IN COMPUTING COURSES: DOES IT MAKE A DIFFERENCE?
}

\author{
Lorraine Staehr, Mary Martin and Graeme Byrne \\ School of Management, Technology and Environment \\ La Trobe University, Bendigo, Australia
}

\begin{abstract}
This paper discusses the outcomes of an intervention programme conducted in 1995 and 1996 at La Trobe University, Bendigo in Australia. The programme was aimed at improving the retention rates of first year women students in computing courses. Anecdotal and survey evidence provided by a pilot programme in 1994 suggested that the problems experienced by the women included: unwillingness to compete for scarce resources, lack of confidence to ask questions in tutorials and laboratory sessions, feelings of intimidation, and misleading preconceptions about the content of computing courses. The intervention programme addressed these problems.
\end{abstract}

The programme was evaluated using both qualitative and quantitative methods to provide a comprehensive picture of the students and the factors affecting their performance in the computing courses.

Structured interviews conducted in 1995 revealed that the pace and content of the first programming subject overwhelmed the women. They lacked confidence in using the computer hardware and were embarrassed to show their ignorance of this. In 1996 structured interviews and focus groups gave a different picture again.

A questionnaire was administered to all first year students in 1995 and 1996. An analysis of covariance (ANCOVA) was performed using the first programming subject result as the dependent variable, and responses from the questionnaire, attendance at the intervention programme and Tertiary Entrance Rank (TER) as terms in the model. Interestingly, the results of the ANCOVA showed that gender, having a home computer, previous user computing experience and attendance at the intervention programme were not significant factors. Final year secondary school mathematics, previous programming experience and year of study were significant factors, with age and the TER of the student highly significant factors.

\section{BACKGROUND}

Poor participation and retention rates of women in computing courses have been reported in a number of countries around the world (Camp 1997, Frenkel 1990, Galpin and Sanders 1993). In Australia the low participation rate of women in tertiary computing courses has been a concern for some time. The Australian Government recognised the problem and identified some strategies for dealing with it in a discussion paper, 'A Fair Chance for All' (DEET 1990) outlining a national objective of $40 \%$ women in nontraditional courses other than engineering by 1995. 
Data showing percentages of women enrolled in computing courses was supplied by delegates from ten Australian universities at the 'Women in Computing' Workshop held at the University of Melbourne in July 1997. Only two universities (VUT and Monash) had courses that reached the DEET objective in recent years. The other universities had maximum enrolments of women in computing courses of around $30 \%$.

The participation rates for women in computing courses at La Trobe University, Bendigo are shown in Table 1 below.

Table 1. Participation Rates of Women in Computing Courses at La Trobe University, Bendigo

\begin{tabular}{||c||c||c||c||c||c||}
\hline Year & Total & $\begin{array}{c}\text { No. of } \\
\text { women }\end{array}$ & $\begin{array}{c}\text { No. of } \\
\text { men }\end{array}$ & \% women & $\%$ men \\
\hline \hline 1994 & 99 & 25 & 74 & 25.3 & 74.7 \\
\hline 1995 & 90 & 29 & 61 & 32.2 & 67.8 \\
\hline 1996 & 112 & 14 & 98 & 12.5 & 87.5 \\
\hline
\end{tabular}

The problem of low numbers of women in undergraduate computing courses has been addressed in a number of tertiary institutions by the development of special programmes. These programmes fall into two main categories: those that focus on increasing the participation rates and those that focus on increasing the retention rates of women. (Craig et al 1998) gives an overview of the programmes offered at universities in Australia.

One method that has been used to increase the retention rates of students in computing courses has involved schemes which provide support networks for first year students. These schemes include peer mentoring (Paay, Gibson and Hartnett 1993, Cartwright and Colville 1994, Craig and Fisher 1995), peer tutoring (Sanders 1995) or a combination of both (Martin, Staehr and Byrne 1996). Some of these programmes have been made available to female students only (Paay, Gibson and Hartnett 1993, Craig and Fisher 1995, Martin, Staehr and Byrne 1996), to both men and women students (Cartwright and Colville 1994, Sanders 1995) and to underachieving students (Sanders 1995). All of these studies (Paay, Gibson and Hartnett 1993, Sanders 1995, Craig and Fisher 1995, Martin, Staehr and Byrne 1996) reported successful outcomes for women students with one exception (Cartwright and Colville 1994).

This paper reports the results of an intervention programme aimed at increasing the retention rates of first year women students. Our programme includes both peer mentoring and peer tutoring.

Table 2 shows the retention rates of women in computing courses at $\mathrm{La}$ Trobe University, Bendigo for the 1993 and 1994 intakes. 
Table 2. Retention Rates of Women in Computing Courses at La Trobe University, Bendigo

\begin{tabular}{||l||c|c||}
\hline \multicolumn{1}{|c||}{} & BComp & BBus/BComp \\
\hline \hline No. Women - 1993 Intake & 12 & 7 \\
\hline No. Women - As at 28/2/94 & 3 & 4 \\
\hline \hline No. Women - 1994 Intake & 11 & 14 \\
\hline No. Women - As at 27/2/95 & 6 & 6 \\
\hline
\end{tabular}

The increased retention rates for the 1994 intake shown in Table 2 indicated that a pilot intervention programme may have had some success. Therefore an intervention programme to address the problem of low retention rates was implemented at La Trobe University, Bendigo in 1995 and 1996. It was developed and adapted from the pilot programme (Staehr and Martin 1995) conducted in 1994. Anecdotal and survey evidence provided by the pilot programme suggested that the problems experienced by the women included: unwillingness to compete for scarce resources, lack of confidence to ask questions in tutorials and laboratory sessions, feelings of intimidation, and misleading preconceptions about the content of computing courses.

The likelihood that students will complete our computing course was investigated using a general linear model which incorporates the students' background characteristics. This model enables prediction of student performance and hence the likelihood that they will continue into the second year of the computing course.

Other studies have attempted to characterise student performance in terms of background characteristics. Cockcroft (1994) uses a method similar to ours except that the dependent variable in her study was calculated from a computer literacy score obtained from a questionnaire. Our dependent variable is the student's result for the first programming subject. Cockcroft (1994) also uses a two-step method to identify significant factors and interactions. However, our method uses a traditional step-wise regression method to arrive at a parsimonious model that is used for subsequent analysis. Taylor and Mounfield (1989) use simple comparative techniques to identify significant influences on student performance in a first computer science subject. They do not attempt to find a model of student performance but rather characterise a successful student profile. Campbell and McCabe (1984) use several multivariate techniques to characterise students according to background factors. They then use discriminant analysis to develop a classification model based on these factors which may be used to analyse and predict student performance.

Our technique is similar to the above methods in that it seeks to use a statistical model to define student performance in terms of background factors. It is difficult to directly compare our work to these studies since the factors considered and the dependent variables differed considerably. However, where it is possible to make comparisons we have agreement in 
some areas and disagreement in others. In particular, we found age a significant factor and gender to be non-significant while other studies (Campbell and McCabe 1984, Cockcroft 1994) found the reverse.

\section{INTRODUCTION}

The two main objectives of the 1995 and 1996 intervention programmes were:

- to investigate the effectiveness of methods employed in the intervention programme for first year women computing students;

- to identify factors in the backgrounds of students which might predict the number of first year computing students continuing into second year.

The students participating in the intervention programme were either from the Bachelor of Computing or the double degree (Bachelor of Business/Bachelor of Computing) at La Trobe University, Bendigo. Neither course requires students to have prerequisite subjects (other than English) for entry, consequently many students enrol with little or no experience in the use of computers or in programming in particular. Students enrolling in the double degree however, must achieve a considerably higher Tertiary Entrance Rank (TER) ${ }^{1}$ to enter the course.

The intervention programme was designed to provide a supportive environment for first year women computing students. The students participated on a voluntary basis with twenty two of twenty nine agreeing to participate in the 1995 programme and fourteen of fourteen in 1996.

It is important to note there was a difference in the academic programme undertaken by the students in 1995 and 1996. In response to the results of the analysis of the qualitative data from the 1995 programme an introductory subject was introduced which was designed to familiarise students with the computer systems on the campus. The students did the 'traditional first programming subject' in semester two in 1996 rather than semester one as in 1995. Successful completion of the first programming subject is defined as a mark of $50 \%$ or more. Success in this subject usually indicates the likelihood of students completing our computing courses.

Another difference in conditions for students in 1995 and 1996 related to hardware resources. The acquisition of a small number of better hardware resources in 1995 meant that students had to become familiar with a number of computer systems. This situation was resolved in 1996 with more new hardware resources available so that students were no longer required to become familiar with more than one computer system. 


\section{METHOD}

\subsection{Intervention Methods}

The three intervention methods implemented in 1995 are described in Martin, Staehr and Byrne (1996). Only one of these methods was used in 1996: weekly study groups of one hour's duration for the participants with women senior students acting as group leaders. Of the other two methods implemented in 1995, one (having the senior students attend practical sessions) had been found to be of little value and the other (ensuring a minimum of $30 \%$ women in the tutorial groups) was not possible due to timetable constraints.

The weekly study group meetings were used to facilitate friendships between the students, provide a non-threatening atmosphere where the students could comfortably ask questions, provide tutorial and assignment assistance and additional access to hardware resources. It was hoped also that the meetings would foster informal mentor networks between the senior students and the first year students. A further ambition for the programme was to provide the environment for the participants to develop into a 'learning community'. (A learning community is a socially constructed cooperative learning environ-ment (Tinto 1995)).

\subsection{Qualitative Data Collection}

In 1995 qualitative data from each participant were obtained by individual structured interviews which were conducted by the research assistant at the beginning of semester two. At the time of the interviews each participant knew her semester one results.

Qualitative data in 1996 were obtained from the participants by using individual structured interviews and focus groups. A research assistant conducted all interviews and focus groups. The interviews took place at the beginning of each semester and at the end of semester two. At the time of the end-of-semester interviews each participant knew her results. The focus groups were conducted in the middle of each semester to obtain a clearer picture of the women students' experiences in first year.

\subsection{Quantitative Data Collection}

A model described in Martin, Staehr and Byrne (1996) was developed for the 1995 data. In this work the 1995 model has been extended to include three additional factors: year of the programme, attendance in the intervention programme and Tertiary Entrance Rank (TER). This new model has been used for the combined 1995 and 1996 data.

The data to identify factors that might predict a student's success were collected using a questionnaire, from attendances at the intervention 
programme meetings, and the students' TERs. The questionnaire was administered to all computing students, including the participants in the intervention programme, at the beginning of semester one in 1995 and 1996.

An analysis of covariance (ANCOVA) was performed using the first programming subject result as the dependent variable and the following data:

- $\quad$ age ( less than 20 years, 20 years and over)

- $\quad$ gender (male, female)

- $\quad$ mathematics subject in Year 11 or 12 (yes, no)

- $\quad$ previous user computing experience (yes - year 12 subject, tertiary or TAFE subject(s), no)

- previous programming experience (yes - year 12 subject, tertiary or TAFE subject(s), no)

- $\quad$ home computer (yes, no)

- $\quad$ course (Bachelor of Computing, other)

- number of attendances in intervention programme

- TER

were used to define the factors in the model. The software package SPSS for Windows Release 7.5.1 was used to perform the ANCOVA. The initial ANCOVA model included main effects and two-way interactions for gender and year with all other terms.

\section{RESULTS}

\subsection{Qualitative}

1995

In 1995 twenty of the twenty two participants were interviewed. The students in the structured interviews specifically mentioned the following information about the intervention programme:

- it provided a safe atmosphere in which they could ask 'dumb' questions (10);

- the intervention programme provided them with the opportunity to get to know other participants (4) and facilitated collaborative learning (2);

- the intervention programme reassured the participants that they were not alone with their problems (3);

- many of the participants (14) felt completely overwhelmed by the pace and content of the first programming subject;

- $\quad$ some of the participants did not relate well with two of the three senior students (5)

the participants lacked confidence in using the computer hardware (4) and were embarrassed to show their ignorance (3);

- $\quad$ some of the participants did not expect to be writing computer programs (4). 
Table 3 shows the retention rate for the 1995 cohort of women computing students. It shows a $44.8 \%$ retention rate.

Table 3. Retention Rates of Women in Computing Courses at La Trobe University Bendigo in 1995

\begin{tabular}{|l|c|c||}
\hline & BComp & BBus/BComp \\
\hline \hline No. Women - 1995 Intake & 17 & 12 \\
\hline No. Women - As at 27/2/96 & 8 & 5 \\
\hline
\end{tabular}

1996

Initial Interviews (Table 4)

Time: First week of semester one Number of students interviewed: 14

Analysis of the interview transcripts provided the results in Table 4. (Note that students may have provided multiple responses or no responses in some instances.)

Focus Group One

Time: Middle of semester one Number of students interviewed: 10

Questions were asked about the senior student, and the perceived advantages of having an all-female study group.

Table 4. Initial Interviews 1996

\begin{tabular}{|c|c|c|}
\hline Question & Response Category & No. \\
\hline \multicolumn{3}{|l|}{ Why did you choose this course? } \\
\hline & Liked computers & 6 \\
\hline & Better career options & 6 \\
\hline & Liked programming & 1 \\
\hline \multicolumn{3}{|l|}{ Who influenced you? } \\
\hline & Careers teacher & 3 \\
\hline & $\begin{array}{l}\text { Teacher other than careers } \\
\text { teacher }\end{array}$ & 5 \\
\hline & Family & 3 \\
\hline & Work experience & 3 \\
\hline & $\begin{array}{l}\text { Liked programming in high } \\
\text { school }\end{array}$ & 1 \\
\hline & Friends & 1 \\
\hline & Own interest & 1 \\
\hline \multicolumn{3}{|l|}{$\begin{array}{l}\text { What are your expectations of } \\
\text { the course? }\end{array}$} \\
\hline & Expect to be hard/a lot of work & 14 \\
\hline & Worried about programming & 1 \\
\hline
\end{tabular}




\begin{tabular}{|c|c|c|}
\hline & $\begin{array}{l}\text { Didn't know if there would be } \\
\text { programming }\end{array}$ & 1 \\
\hline & None & 2 \\
\hline \multicolumn{3}{|l|}{$\begin{array}{l}\text { What job do you expect to get at } \\
\text { the end of the course? }\end{array}$} \\
\hline & $\begin{array}{l}\text { Computing, but related to } \\
\text { accounting }\end{array}$ & 1 \\
\hline & Programming & 3 \\
\hline & Accountant & 3 \\
\hline & Computer auditing & 1 \\
\hline & Systems analyst & 2 \\
\hline & Business & 1 \\
\hline & Don't know & 3 \\
\hline \multirow[t]{4}{*}{$\begin{array}{l}\text { Do you expect to work in } \\
\text { computing, another area and use } \\
\text { your knowledge of computing or } \\
\text { in an area which does not require } \\
\text { computing? }\end{array}$} & & \\
\hline & Computing & 6 \\
\hline & $\begin{array}{l}\text { Another area and use your } \\
\text { knowledge of computing }\end{array}$ & 5 \\
\hline & Don't know & 4 \\
\hline \multirow[t]{6}{*}{$\begin{array}{l}\text { Give an indication of what you } \\
\text { would expect to be doing on a } \\
\text { daily basis in your chosen job. }\end{array}$} & & \\
\hline & Design a program for business & 2 \\
\hline & $\begin{array}{l}\text { Combination of business and } \\
\text { computing }\end{array}$ & 1 \\
\hline & Programming in teams & 1 \\
\hline & Computers and programming & 1 \\
\hline & Don't know & 9 \\
\hline
\end{tabular}

The senior student:

- didn't expect them to know anything and therefore didn't make them feel dumb;

- $\quad$ was happy to go back to basics and made it simple;

- $\quad$ helped with assignments when they had no idea where to start.

The participants were very happy to have an all women study group because:

- $\quad$ some students were intimidated by the males, whom they felt make them feel dumb;

- it is the only place to meet other women as most are in all male tutorials.

The disadvantages of an all women study group are:

- that it is unfair for males in the same position as the women, i.e. they have never done computing before. 
- many of the women are teased by the males for getting this extra help.

All students did a non-programming Information Technology subject in their final year at secondary school and said they either were not aware of the availability of a programming subject, were not encouraged to do it, or it was not offered.

Second Interview (Table 5)

Time: First week of semester two

Number of students interviewed: 10

Table 5. Second Interview 1996

\begin{tabular}{|c|c|c|}
\hline Question & Response Category & $\overline{\text { No. }}$ \\
\hline \multicolumn{3}{|l|}{$\begin{array}{l}\text { Why did you participate in the } \\
\text { intervention programme? }\end{array}$} \\
\hline & Extra help for programming & 8 \\
\hline & All women & 2 \\
\hline & To meet other women & 1 \\
\hline \multirow{2}{*}{\multicolumn{3}{|c|}{$\begin{array}{l}\text { What were the good things about } \\
\text { the study group? }\end{array}$}} \\
\hline & & 8 \\
\hline & Getting extra help & 10 \\
\hline & $\begin{array}{l}\text { Didn't feel stupid asking } \\
\text { questions }\end{array}$ & 1 \\
\hline & $\begin{array}{l}\text { Someone other than lecturer or } \\
\text { tutor }\end{array}$ & 1 \\
\hline & The senior student & 4 \\
\hline & Study techniques & 1 \\
\hline \multicolumn{3}{|l|}{$\begin{array}{l}\text { What were the bad things about } \\
\text { the study group? }\end{array}$} \\
\hline & None & 4 \\
\hline & Study techniques & 1 \\
\hline & Rushed for time & 1 \\
\hline & No males & 1 \\
\hline
\end{tabular}

Focus Group Two

Time: Middle of semester two Number of students interviewed: 8

Questions were asked about the programming subject they were currently undertaking and the introductory computing subject done in the first semester. (Some responses were lost due to a faulty microphone.)

The participants:

- $\quad$ strongly supported the study group as the level of difficulty of the first programming subject was perceived to be high (most of the discussion focused on this); 
- felt that the introductory computing subject they had done in semester one had provided practical basics and developed their confidence;

- $\quad$ suggested that the introductory subject should include an introduction to programming;

- were extremely happy and comfortable with the senior student. Final Interviews (Table 6)

Time: When semester two results available

Number of students interviewed: 6

Table 6. Final Interviews 1996

\begin{tabular}{||l||l||c||}
\hline \hline Question & Response Category & No. \\
\hline \hline $\begin{array}{l}\text { Has the study group been useful to } \\
\text { you personally? How? }\end{array}$ & & 2 \\
\hline & Exam revision & 1 \\
\hline & Good to know the support is there & 1 \\
\hline & $\begin{array}{l}\text { Knowing other people have the } \\
\text { same problems }\end{array}$ & 2 \\
\hline & Helpful for assignments & 1 \\
\hline & Liked casual atmosphere & 1 \\
\hline & $\begin{array}{l}\text { Didn't attend regularly - felt } \\
\text { lukewarm about it }\end{array}$ & \\
\hline
\end{tabular}

Table 7 shows the retention rate for the 1996 first year women computing students. It shows a $71 \%$ retention rate.

Table 7. Retention Rates of Women in Computing Courses at La Trobe University Bendigo in 1996

\begin{tabular}{|l|c|c|}
\hline & BComp & BBus/BComp \\
\hline \hline No. Women - 1996Intake & 6 & 8 \\
\hline No. Women - As at 27/2/97 & 3 & 7 \\
\hline
\end{tabular}

\subsection{Quantitative}

The 1995 and 1996 data were combined giving a total sample size of 122 . The model described in the method section was estimated and nonsignificant terms removed one-at-a-time. The adjusted $\mathrm{R}$-squared value was used to compare models at each stage in the removal process. The final model shown in Table 8 has four main effect terms and just one interaction term with an adjusted $\mathrm{R}$-squared value of 0.462 . This value is not significantly different from the adjusted R-squared value of the initial model containing all main effects and two-way interaction terms.

The parameter estimates for the model are shown in Table 9. These estimates show that on average: 
- the over 20 age group scored $21.0 \%$ higher than the under 20 age group;

- $\quad$ students with a previous programming subject scored $9.7 \%$ higher than those without;

- students with a mathematics subject at year 11 or 12 scored $16.6 \%$ higher than students with no mathematics in these years;

- $\quad$ students in 1996 scored $21.1 \%$ better than students in 1995 and an increase of 1 TER point implies an increase of $0.366 \%$ in the first programming subject result in 1996 while in 1995 it implies an increase of $0.637 \%$.

Table 8. Analysis of Covariance

Dependent Variable: First Programming Subject Result

\begin{tabular}{|c|c|c|c|c|c|}
\hline Source & $\begin{array}{l}\text { Type III } \\
\text { Sum of } \\
\text { Squares }\end{array}$ & df & $\begin{array}{l}\text { Mean } \\
\text { Square }\end{array}$ & $F$ & Sia \\
\hline $\begin{array}{l}\text { Corrected } \\
\text { Model }\end{array}$ & $24632.701^{b}$ & 6 & 4105.450 & 18.285 & .000 \\
\hline Intercept & 10480.799 & 1 & 10480.799 & 46.681 & .000 \\
\hline AGE & 3175.081 & 1 & 3175.081 & 14.142 & .000 \\
\hline PROG & 2231.683 & 1 & 2231.683 & 9.940 & .002 \\
\hline MATHS & 1242.261 & 1 & 1242.261 & 5.533 & .020 \\
\hline YEAR & 1773.701 & 1 & 1773.701 & 7.900 & .006 \\
\hline TER & 14146.039 & 1 & 14146.039 & 63.006 & .000 \\
\hline $\begin{array}{l}\text { YEAR * } \\
\text { TER }\end{array}$ & 1048.117 & 1 & 1048.117 & 4.668 & .033 \\
\hline Error & 25819.758 & 115 & 224.520 & & \\
\hline Total & 478208.0 & 122 & & & \\
\hline $\begin{array}{l}\text { Corrected } \\
\text { Total }\end{array}$ & 50452.459 & 121 & & & \\
\hline
\end{tabular}

a. Computed using alpha $=.05$

b. $R$ Squared $=.488$ (Adjusted $R$ Squared $=.462$ ) 
Table 9. Parameter Estimates

\begin{tabular}{|c|c|c|c|c|}
\hline $\begin{array}{l}\text { Dependent } \\
\text { Variable }\end{array}$ & Parameter & $B$ & Std. Error & Sig. \\
\hline First & Intercept & 69.647 & 7.146 & .000 \\
\hline \multirow{11}{*}{$\begin{array}{l}\text { Programming } \\
\text { Subject Result }\end{array}$} & [AGE=1.00] & -21.024 & 5.591 & .000 \\
\hline & [AGE=2.00] & 0 & & \\
\hline & {$[\mathrm{PROG}=.00]$} & -9.703 & 3.078 & .002 \\
\hline & {$[P R O G=1.00]$} & 0 & & \\
\hline & [MATHS=.00] & -16.623 & 7.067 & .020 \\
\hline & [MATHS=1.00] & 0 & & \\
\hline & [YEAR=1995.00] & -21.090 & 7.503 & .006 \\
\hline & [YEAR=1996.00] & 0 & & \\
\hline & TER & .366 & .090 & .000 \\
\hline & $\begin{array}{l}\text { [YEAR=1995.00] } \\
{ }^{*} \text { TER }\end{array}$ & .271 & .126 & .033 \\
\hline & $\begin{array}{l}{[\text { YYEAR=1996.00] }} \\
\text { * TER }\end{array}$ & 0 & & \\
\hline
\end{tabular}

\section{DISCUSSION}

Data obtained from the intervention programme in 1995 provided the basis for introducing an introductory computing subject the following year. The 1995 group had found the first programming subject overwhelming and felt they needed the study groups to cope. In 1996 the students found the programming subject difficult but not overwhelming. Feedback from the participants in 1996 indicated the inclusion of the introductory computing subject was successful.

Another reason for the students finding the first programming subject overwhelming in 1995 may have been due the number of computer systems they were required to learn to use. The ANCOVA also indicated that the year of the programme was highly significant, suggesting that all students found the introductory subject and the improved hardware resources in 1996 beneficial.

There was strong support for the all women study groups in both years. This was despite the fact that the some of the women felt it was unfair to the men in the course and that they were teased by the men. The opportunities the study group provided to meet other women were mentioned more than once. Formation of friendship groups may improve retention rates as loneliness and getting to know other students has been cited as a factor in research into the first year student experience (Pitkethly 1997). 
The results of the initial interviews in 1996 indicate the ways in which more women could be encouraged to enrol in computing courses. Teachers (including careers teachers) seem to have the greatest influence on the women choosing a computing course. However the women had very limited knowledge of the variety of computing careers available. If teachers were more informed about the variety of computing careers this may improve the promotion of computing courses to young women. This problem is not new and was reported by Ward (1991).

All the women in 1996 expected the computing course to be difficult. This perception may explain the small numbers of women entering computing courses. Research has shown that adolescent females in western societies learn to avoid demanding situations whereas adolescent males learn to deal with them (Campbell and McCabe 1984). Another factor to consider is the name of the course. Interestingly, the names of both university courses ('Information systems' and 'Business computing') which have achieved the DEET objective of $40 \%$ participation of women do not imply technical computing.

Table 10 shows the retention rates after one year of the women in computing courses at La Trobe University, Bendigo. In 1993 there was no intervention programme. The pilot programme ran in 1994 and the intervention programme was implemented in 1995 and conducted again in 1996. The retention rate in 1993 with no intervention programme is lower than the later years when the intervention programme was conducted. This suggests that the intervention programme may have increased the retention rates of women students.

\section{Table 10. Retention Rates of Women in Computing Courses After One Year}

\begin{tabular}{||l||c|c|c||}
\hline \hline & BComp & $\begin{array}{c}\text { BBus/ } \\
\text { BComp }\end{array}$ & Retention Rate \\
\hline \hline No. Women - 1993 Intake & 12 & 7 & \\
\hline No. Women - As at 28/2/94 & 3 & 4 & $7 / 19=36.8 \%$ \\
\hline \hline No. Women - 1994 Intake & 11 & 14 & \\
\hline No. Women - As at 27/2/95 & 6 & 6 & $12 / 25=48 \%$ \\
\hline \hline No. Women - 1995 Intake & 17 & 12 & \\
\hline No. Women - As at 27/2/96 & 8 & 5 & $13 / 29=44.8 \%$ \\
\hline \hline No. Women - 1996 Intake & 6 & 8 & \\
\hline No. Women - As at 27/2/97 & 3 & 7 & $10 / 14=71 \%$ \\
\hline
\end{tabular}

The large difference in retention rate of $71 \%$ in 1996 compared with $44.8 \%$ in 1995 may be explained by the differences in TERs of the two groups of women students. With only one exception the women who entered the computing courses in 1996 all had average-to-high TERs. There was a much broader range of TERs amongst the women in 1995. Given that TERs are a significant factor in the model, and that the students' success in the first 
programming subject is an indicator of success in the remainder of the course, this may provide an explanation of the differing retention rates over the two years.

Our model shows that previous programming experience is a significant factor in predicting a student's success in the first programming subject. Taylor and Mounfield (1989) also found prior programming experience was a major factor for success in computer science at tertiary level. There is only one subject at university entrance level in Victoria that teaches programming. This subject is rarely offered in country high schools due to the small numbers of students. This disadvantages not only women but all rural students.

The study of mathematics in the final years of high school was a significant factor in the model. Other researchers (Campbell and McCabe 1984) have found that background in high school mathematics is a predictor of success in computer science. However it should be noted that our computing courses do not require mathematics prerequisites, as do computer science courses.

The age of the student was found to be a significant factor in the model. This is not surprising as mature age students usually perform well in contrast to school leavers.

An increase of one TER point implies a smaller $(0.366 \%)$ increase in the first programming subject result in 1996 than in $1995(0.637 \%)$. This indicates that the introductory computing subject and the improved hardware resources lessened the effect of TER on the first programming subject result.

Gender, previous user computing experience, number of attendances at the intervention programme, the course taken, and the possession of a home computer were all found to be not significant.

\section{CONCLUSION}

This study had two main objectives: to investigate the effectiveness of methods employed in the intervention programme for first year women computing students, and to identify factors in the backgrounds of all students which might predict the number of first year computing students continuing into second year.

Of the methods employed in the programme, only the study groups facilitated by senior students were implemented in both 1995 and 1996. The improved retention rate as the programme was refined over the years $1994-$ 1996 suggests that the study group has been effective. The qualitative data also provided evidence that the study group was appreciated and strongly supported in both years. Getting to know other students and assistance with studies were the main reasons given for support of the study group concept. 
The poor retention rate for women in 1993 and subsequent improvements along with anecdotal evidence lead us to believe that the intervention programme has produced positive outcomes for women students.

The ANCOVA pointed to five factors which might predict success in computing: if the student (1) was 20 years old or more (2) had a high university entrance score, (3) had previous programming experience, (4) had done a mathematics subject at year 11 or 12, and (5) studied the subject in 1996. None of the first four factors are surprising. It is well accepted that older students generally do very well when they return to study. Programming experience and mathematical backgrounds have been reported as significant in previous studies by other researchers. Similarly one would naturally expect that a student with a high university entrance score would do better than a student with a lower score.

The size of the year effect (21.1\%) was unexpected. However we feel the improved hardware resources and the new introductory computing subject have combined to produce this very positive outcome for all students. It should be noted that the introduction of the new computing subject was based on the results of the qualitative analysis in 1995 .

Future work will involve continuing the qualitative aspects of the study and comparing predictions from the model with the actual outcomes obtained, thereby assessing the usefulness of the model as a predictive tool.

\section{Acknowledgement}

The 1996 intervention programme was supported by a grant from the Equity and Access Unit, La Trobe University, Australia.

\section{NOTES}

1 University entrance score in Victoria, Australia

\section{REFERENCES}

Camp, T. (1997) The Incredible Shrinking Pipeline. Communications of the ACM 40(10) $103-110$.

Campbell, P.F. and McCabe, G.P. (1984) Predicting the Success of Freshmen in a Computer Science Major. Communications of the ACM 27(11) 1108-1113.

Cartwright, A. and Colville, P. (1994) A Mentor Scheme for Bachelor of ComputingStudents. Broadening the Network - Women in Computing Conference, QUT, Brisbane, Australia, 4-6 July, 1-11.

Cockcroft, S. (1994) The Effects of Gender and Computer Access on Computer Literacy Scores among First 
Year Undergraduates. In Adam, A. and Owen, J. (eds.) Proceedings of the $5^{\text {th }}$ IFIP International Conference on Women, Work and Computerisation, Manchester, UK, 2-5 July, pp. 421-434.

Craig, A and Fisher, J. (1995) A Peer Mentoring Scheme to Encourage and Retain Female Business Computing Students. Pacific Rim First Year Experience Conference, Brisbane, Australia, July, ISBN 1864351632 [published on disk].

Craig, A., Fisher, J., Scollary, A. and Singh, M. (1998) Closing the Gap - Women Education and Information Technology Courses in Australia. Journal of Systems Software 40(1) 7-15.

DEET (1990) A Fair Chance for All: Higher Education That's Within Everyone's Reach, Discussion Paper, Australian Government Publishing Service.

Frenkel, K. (1990), Women and Computing. Communications of the ACM 33(11) 34-46.

Galpin, V. and Sanders, I. (1993) Gender Imbalances in Computer Science at the University of Witwatersrand. SIGCSE Bulletin 25(4) 2-4.

Martin, M., Staehr, L. and Byrne, G. (1996) An Intervention Program for First Year Female Computing Students. GASAT Australia, New Zealand and South Pacific $2^{\text {nd }}$. Regional Conference, Auckland, N.Z., ISBN 0-908689-52-7, pp. 79-85.

Paay, P., Gibson, R. and Hartnett, J. (1993) not(The Power of One): Building Networks with a Mentor Scheme. In Fisher, J. (ed.) Networking for the 90s, Proceedings of the Second Women in Computing Conference, Melbourne, Australia, 11-14 July, pp. 60-69.

Pitkethly, A. (1997) Academic Development Unit, La Trobe University.

Sanders, I. (1995) A Peer-tutoring Programme in Computer Science at the University of Witwatersrand. GATES 2(1) 38-46.

Staehr, L. and Martin, M. (1995) Improving the Retention Rates of First Year Females in Computing Courses. Pacific Rim First Year Experience Conference, Brisbane, Australia, July, ISBN 1864351632 [published on disk].

Taylor, H.G. and Mounfield, L.C. (1989) The Effect of High School Computer Science, Gender and Work on Success. SIGCSE Bulletin 21(1) 195-198.

Tinto, V. (1995) Learning communities and the Reconstruction of the first Year Experience. Keynote Speaker, Pacific Rim First Year Experience Conference, Brisbane, Australia.

Ward, R. (1991) Computing in Schools: the Same Old Story. In Lovegrove, G. and Segal, B. (eds.) Women into Computing: Selected Papers 1988 -1990. Springer-Verlag, London, pp. 14-19. 